\title{
CITIZEN JOURNALISM: KELAYAKAN BERITA DITINJAU DARI SEGI BAHASA DAN ETIKA JURNALISTIK
}

\author{
Anhar Fazri \\ Dosen Ilmu Komunikasi Fakultas Ilmu Sosial dan Politik Universitas Teuku Umar \\ Email: faj_del06@yahoo.com
}

\begin{abstract}
The era of journalism today increasingly provide freedom for all people who want to present the results of the journalistic works, namely with a growing phenomenon of citizen journalism. However, the problems that occur, namely the citizen journalism that has not yet entirely understand how to issue a code of conduct and also grammar in presenting a news so it will give an assessment about the worth or whether a news. The development of the concept of citizen journalism originated from the emergence of the internet world. However, that does not mean such conservation media print and electronic media cannot accommodate the writings that are the result of a process of citizen journalism. In addition to the electronic and print media, the current online media also continues to develop and provide a place for who want to create news reports they do, such as kompasiana.com, tribun Yogya and other. The results of the citizen journalism reports sent to the mass media by way of via email. The number of communities that ultimately plunging into a citizen journalist, raises a big question, whether they produce news later deserve to be consumed using the theory of community news, Citizen Journalism and the Ethics of journalism Indonesia.
\end{abstract}

Keywords: Feasibility News, Citizen Journalism, Journalism Code of Ethics

\section{PENDAHULUAN}

Media massa pada saat ini merupakan salah satu bagian terpenting dalam kehidupan masyarakat. Hal ini, banyak didasari berbagai factor dan juga mendorong masyarakat untuk membaca, dan menulis. Media juga berperan bagi masyarakat sebagai wadah dimana masyarakat mendapat tempat baik itu sebagai objek dan juga pada tempat tertentu menjadi subjek.

Perkembangan media massa dapat dikelompokkan ke dalam tiga bentuk yaitu media cetak, media elektonik dan media online. Ketiga media massa tersebut identik dengan sebutan dunia pers. Pers tidak hanya mengelola suatu pemberitaan, akan tetapi juga membahas berbagai aspek-aspek lainnnya untuk isi dari media massa. Karena itu, fungsinya tidak hanya menyiarkan informasi, tetapi juga menyerap aspirasi pembaca atau menjadi stimulus bagi pembaca.

Saat ini berkembang dan juga menjadi salah satu dari bagian media massa yaitu Citizen Journalism. Sebagai sarana komunikasi massa, surat kabar memiliki berbagai macam bentuk informasi yang disuguhkan kepada pembaca. Citizen Journalism muncul pada tanggal 19 januari 1998, saat Mrak Drudge menuliskan berita di internet terkait kasus perselingkuhan yang dilakukan oleh Presiden Amerika Serikat, Bill Clinton dengan salah satu seorang stafnya yakni Monica Lewinsky atau yang lebih dikenal dengan kejadian Monicagate (Irianto, 2005:123). Lahirnya konsep citizen journalism sangat berkaitan erat dengan gerakan civic journalism atau disebut juga public journalism (jurnalisme publik) di Amerika Serikat setelah pemilihan presiden tahun 1988. Gerakan jurnalisme publik ini 
muncul karena krisis kepercayaan publik Amerika terhadap media-media mainstream dan kekecewaan terhadap kondisi politik saat itu (Kusumaningati, 2012:7)

Citizen journalism menjadikan masyarakat sebagai obyek sekaligus subyek berita yang membuat setiap orang bisa menjadi penulis. Dan hal ini bukan bentuk persaingan media, namun merupakan sebuah bentuk perluasan media. Dengan melibatkan masyarakat secara langsung baik sebagaik objek dan subjek berita maka menambah citizen journalism menjadi lebih menarik karena antara jumlah berita dalam koran yang lebih sedikit dibandingkan dengan jumlah blog yang ada. Blog yang ada jumlahnya banyak sekali, dengan begitu setiap orang bebas memilih berita sendiri.

Saat ini, konsep citizen journalism berkembang dengan lebih cepat karena audience dimudahkan dengan adanya fasilitas internet. Beberapa media cetak di Indonesia juga sudah mengembangkan sayapnya dengan versi online, yang menyediakan kolom khusus bagi warga yang ingin berkomentar akan tulisan yang di posting atau bahkan dapat langsung mengirimkan karya tulis jurnalistiknya. Namun, bukan berarti media konvesional seperti surat kabar tidak dapat menampung tulisan-tulisan yang merupakan hasil proses jurnalistik warga. Mengacu pada pendapat Nurudin (2009), konsep citizen journalism di media cetak sesungguhnya sudah ada sejak dulu dalam bentuk surat pembaca.

Namun, bukan berarti berita yang dikirimkan oleh citizen journalist sudah layak diterima oleh masyarakat. Oleh karena itu, dalam tulisan ini penulis akan membahas tentang kelayakan berita yang dihasilkan oleh para citizen journalist dalam pada media massa yang mengacu pada Kode Etik Jurnalistik Indonesia, di mana seorang wartawan Indonesia harus bersikap independen dan menghasilkan berita yang akurat, berimbang dengan cara wartawan Indonesia harus bersikap profesional dalam melaksanakan tugas jurnalistiknya dan tidak mencampurkan fakta dan opini yang menghakimi, serta menerapkan asas praduga tak bersalah.

\section{PEMBAHASAN}

\section{Citizen Journalism}

Bersamaan dengan perkembangan teknologi dan komunikasi, praktik pencarian informasi mulai berubah. Masyarakat mulai aktif terlibat dalam pencarian berita. Hal ini dikarenakan audiens merasa banyak informasi yang terabaikan di media massa mainstream Quinn \& Lamble (2008:40). Warga biasa yang tidak terlatih sebagai wartawan dengan peralan teknologi informasi yang dimiliki mulai meliput, mencatat, mengumpulkan, menulis dan menyiarkannya hal ini disebut dengan citizen journalism. Selain citizen journalism nama lainnya yang sering muncul untuk menunjukkan kegiatan warga menulis laporan peristiwa di internet adalah participatory journalism, public journalism, democratic journalism, independent journalism, wiki journalism, open-source journalism dan street journalism (Pepih, 2012: 18-20).

Konsep dimana warga biasa melakukan tindakan jurnalisme dalam sejarah merupakan memiliki sejarah panjang di dunia sama panjangnya dengan sejarah jurnalistik dahulu. Dikutip dari Pepih (2012: 8), Gillmor merunut akar peristiwa jurnalisme warga terjadi di akhir tahun 1700-an yang menurutnya adalah awal dari dimulainya kegiatan warga biasa, warga independen yang memulai menulis dan menyebarkan gagasannya lewat pamflet atau selebaran. Di Korea Selatan, situs citizen journalism OhMyNews.com menjadi populer dan sukses secara komersil, Dengan motto "Every Citizen is a Reporter" diprakrasai oleh Oh Yeon Ho pada Februari tahun 2000, OhMyNews.com diperkirakan telah mempunyai 50.000 pewarta warga di seluruh Korea Selatan dan turut membantu perubahan kondisi politik di Korea Selatan yang dulu konservatif menjadi lebih demokratis (Lee Tusman, 2010: 299). 
Di Indonesia, citizen journalism mulai menjadi sebuah fenomena baru dikalangan masyarakat yaitu pada saat kejadian bencana tsunami di Nangroe Aceh Darussalam pada bulan Desember 2004. Hal ini bisa diperhatikan dari banyaknya rekaman-rekaman dari warga dan juga tulisan-tulisan yang membantu media mainstream dalam memberikan reportase untuk pemirsanya. Dengan alat perekam seadanya berupa handycam, telpon genggam dan kamera digital, masyarakat bisa turut aktif dalam kegiatan liputan dan laporan jurnalistik. Gillmor dalam Arif (2010:158) menyebut bencana gempa tersebut sebagai titik balik kemunculan jurnalisme warga. Blog, situs web, situs micro blog dan sms melalui telpon genggam mengalahkan sebaran berita di media massa konvensional. Fenomenafenomena ini menurut Gillmor merupakan pertanda bangkitnya citizen journalism. Kata kuncinya disini adalah "kebangkitan" bukan "lahir" karena pada dasarnya sejarah citizen journalism sama dengan sejarah jurnalistik dahulu.

Lasica, seorang online journalist dan social media consultant mengkategorikan citizen journalism (www.ojr.org, diakses pada 15 September 2015) menjadi enam kategori, yaitu:

1. Audience Participation (seperti komentar user yang di attach pada kisah-kisah berita, blog-blog pribadi, video, footage yang diambil dari handycam pribadi atau berita lokal yang ditulis oleh anggota komunitas.

2. Situs web berita atau informasi independen (Customer Reports, Drudge Report),

3. Situs berita partisipatoris murni (OhMyNews, Kompasiana, Citizen6),

4. Situs media kolaboratif (slashdot, kuroshin),

5. Bentuk-bentuk lain dari media tipis (mailing list, newsletter email),

6. Situs penyiaran pribadi (situs penyiaran audio, seperti Ken Radio)

Kehadiran internet telah semakin memperpendek siklus berita tersebut. Hal ini terjadi, karena internet telah menyediakan fasilitas untuk update dan upload berita dengan mudah sehingga hanya dalam hitungan menit berita dapat segera tersaji di layar kaca komputer para pembaca (Darmadi, 2006: 106-109).

Jay Rosen seorang profesor dari New York University dalam Mendolora (2011, vocus.com diakses pada 16 September 2015), menyimpulkan bahwa citizen journalism online adalah ketika seseorang yang dahulunya diketahui sebagai seorang audience menggunakan kemampuan yang mereka miliki untuk menginformasikan sesuatu kepada orang lain. Saat ini citizen journalism merupakan elemen nyata dalam perkembangan media dewasa ini. Teknologi sangat penting bagi citizen journalism online, perkembangan teknologi dan komunikasi telah membuat, menulis, mempublikasikan dan menyebarkan berita lewat teks, audio maupun video atau kombinasi mereka berdua sangat mudah untuk diakses publik.

\section{Tinjauan Tentang Berita}

Charnley dalam Amir (2005: 43) mendefinisikan berita sebagai laporan tercepat dari suatu peristiwa atau kejadian sebenarnya, penting dan menarik bagi pembaca serta menyentuh kepentingan mereka. Suatu fakta dapat dikatakan berita, apabila memenuhi syarat antara lain telah dipublikasikan oleh seseorang atau institusi yang jelas identitasnya, alamat, dan penanggung jawabnya, fakta tersebut ditemukan oleh jurnalis dengan cara yang sesuaidengan standar operasional dan prosedur dalam profesi jurnalistik (Panuju, 2005 : 52).

Selain unsur-unsur berita wartawan juga harus memikirkan nilai berita, dalam cerita atau berita itu tersirat pesan yang ingin disampaikan wartawan kepada pembacanya. Effendy (2003: 67) merumuskan nilai-nilai berita sebagai berikut: 
1. Aktualitas, berita tak ubahnya seperti es krim yang gampang meleleh, bersamaan dengan berlalunya waktu nilainya semakin berkurang. Bagi surat kabar, semakin aktual berita-beritanya, artinya semakin baru peristiwa itu terjadi, maka semakin tinggi nilai beritanya.

2. Kedekatan, peristiwa yang mengandung unsur kedekatan dengan pembaca akan menarik perhatian. Kedekatan yang dimaksud tidak hanya kedekatan secara geografis tapi juga kedekatan emosional.

3. Keterkenalan, kejadian yang menyangkut tokoh terkenal (prominent names) memang akan banyak menarik pembaca. Hal ini tidak hanya sebatas nama orang saja, demikian pula dengan tempat-tempat terkenal,

4. Dampak, suatu peristiwa yang diakibatkan dari pengaruh suatu berita. Berita-berita yang dapat mempengaruhi khalayak seperti ini artinya mempunyai nilai berita.

\section{Jenis Berita}

Ishwara (2011: 75-84) menguraikan bahwa berita terbagi menjadi dua jenis, yaitu berita yang terpusat pada peristiwa (event-centered news) dan berita yang berdasar pada proses (process-centered news), yang definisinya adalah sebagai berikut:

\section{a. Berita terpusat pada peristiwa;}

Berita yang terpusat pada peristiwa menyajikan peristiwa hangat yang baru terjadi, dan umumnya tidak diinterpretasikan, dengan konteks yang minimal, tidak dihubungkan dengan situasi dan peristiwa yang lain.

b. Berita yang berdasar pada proses;

Berita yang berdasar pada proses yang disajikan dengan interpretasi tentang kondisi dan situasi dalam masyarakat yang dihubungkan dengan konteks yang luas dan melampaui waktu. Berita semacam ini muncul di halaman-halaman khusus seperti editorial, feature dan laporan khusus.

\section{Unsur Kelayakan dalam Berita}

Kusumaningrat (2005: 47-58) menilai ada lima sifat istimewa berita yang membangun prinsip-prinsip kerja dan menentukan bentuk-bentuk praktik pemberitaan yang berlaku sebagai pedoman dalam menyajikan dan menilai kelayakan dari suatu berita, unsurunsurnya adalah sebagai berikut:

a. Berita harus akurat, artinya penulis berita tidak boleh mengabaikan soal akurasi dan berhati-hati dalam menulis fakta-fakta yang didapat dari sumber berita.

b. Berita harus lengkap, adil dan seimbang artinya seorang penulis berita harus melaporkan apa yang terjadi dengan sesungguhnya dengan mengumpulkan fakta yang proporsional, wajar serta berimbang.

c. Berita harus objektif, artinya berita yang dibuat harus selaras dengan kenyataan, tidak berat sebelah dan bebas dari prasangka..

d. Berita harus ringkas dan jelas, artinya berita yang disajikan haruslah dapat dicerna dengan cepat, ringkas, jelas dan sederhana, tidak banyak menggunakan kata-kata, harus langsung padu.

e. Berita harus hangat, artinya berita haruslah bersifat baru karenam masyarakat membutuhkan berita untuk dapat memenuhi kebutuhan mereka akan suatu informasi dan dapat mengambil keputusan yang tepat saat dibutuhkan. 


\section{Nilai Berita (News Value)}

Menurut Ishwara (2011: 76) suatu berita memiliki pesan tersirat yang ingin disampaikan kepada pembacanya. Dalam berita ada karakteristik intrinsik yang dikenal sebagai nilai berita (news value). Nilai berita ini menjadi ukuran yang berguna untuk menentukan layak berita (newsworthy). Nilai-nilai berita tersebut sebagai mana dirangkum dari Ishwara (2011: 76 - 81) adalah sebagai berikut:

a. Konflik

Kebanyakan konflik adalah layak berita. Konflik fisik mempunyai nilai berita karena biasanya terdapat kerugian dan korban serta menyangkut hajat hidup orang banyak.

b. Kemajuan dan Bencana

Dari perjuangan hidup yang rutin, yang umumnya tidak layak berita, sering muncul keberhasilan yang gemilang. Dari riset dan uji coba lahir penemuan baru, alat-alat serta pengobatan baru. Demikian pula kebakaran dan bencana alam seperti gempa, gunung meletus, banjir semua dapat terjadi secara tiba-tiba.

c. Kemasyhuran dan Terkemuka

Telah disetujui bahwa nama membuat berita dan nama besar membuat berita itu menjadi lebih besar. Harus ada tindakan agar perubatan nama itu, baik besar atau kecil menjadi berita. Hal yang mereka lakukan atau katakan sering kali menjadi berita karena ada konsekuensi yang mengakibatkan timbulnya rangkaian peristiwa yang dapat mempengaruhi banyak orang.

d. Kedekatan

Kedekatan dan saat yang tepat adalah ukuran yang diterapkan pada berita untuk menentukan apakah layak dihimpun atau dapat dijual. Salah satu aset utama dari berita adalah kesegaran (freshnessI). Kecelakaan lalu lintas hari ini pada jam sibuk lebih layak berita daripada kecelakaan lalu lintas serupa seminggu yang lalu. Ini mengenai momen yang tepat. Begitu pula kecelakaan setempat lebih layak dari kecelakaan serupa di kota lain.

e. Keganjilan

Keganjilan yang kerap kita lihat dalam berita misalnya mengenai anak sapi berkepala dua termasuk kejadian yang luar biasa. Seperti juga kejadian yang sangat kontras, cara hidup yang ganjil, kebiasaan dan hobi yang tidak umum, ketahkyulan termasuk menarik perhatian pembaca.

f. Human Interest

Banyak cerita di surat kabar yang bila dilihat sepintas tidak seperti berita karena tidak memenuhi unsur-unsur konflik, konsekuensi, progres dan bencana, keganjilan atau nilai berita lainnya.

\section{Tinjauan tentang Wartawan}

Asal kata wartawan adalah warta yang berarti berita atau kabar, ditambah imbuhan -wan yang dipakai untuk orang yang mata pencahariannya atau pekerjaannya terletak di bidang tertentu. Wartawan menurut KBBI artinya adalah orang yang pekerjannya mencari dan menyusun berita untuk dimuat di surat kabar, majalah, radio dan televisi.

Sarwono $(2008,110)$ mendefinisikan wartawan sebagai praktisi komunikasi yang berbekal fakta dan opini sebagai bahan mentah pesan yang kemudian dikemas dan diteruskan kepada massa melalui media massa. Wartawan sebagai mediator sekaligus komunikator mempunyai niat untuk tidak menyia-nyiakan pesan, apalagi jika memang diperlukan atau dianggap penting oleh khalayak. Dalam Wibowo (2009, 56) Assegaf (1991) 
mendefinisikan wartawan sebagai orang yang bekerja dan mendapat nafkah sepenuhnya dari media massa. Namun seiring dengan perkembangan zaman dan tuntutan informasi yang sedemikian besar, banyak warga biasa yang tidak terlatih sebagai wartawan profesional dengan peralatan teknologi informasi yang dimilikinya meliput, mencatat, mengumpulkan, menulis dan menyiarkannya di media online, bermodalkan semangat berbagi dengan pembaca lainnya, mereka diidentifikasi oleh Pepih $(2008,18)$ sebagai seorang citizen journalist.

\section{Bahasa Jurnalistik}

Membuat berita jurnalistik yang baik dan benar bukanlah persoalan yang mudah apalagi ketika memperhatikan kode etik jurnalistik dan bahasa yang digunakan. Oleh karena itu, penggunaan bahasa juga sangat mempengaruhi kualitas baik dan tidaknya sebuah berita yang dihasilkan oleh media massa. Menurut Sumandiria (2006:7) Bahasa jurnalistik adalah bahasa yang digunakan oleh para wartawan, redaktur, atau pengelola media massa yang menyusun dan menyajikan, memuat, menyiarkan, dan menayangkan berita serta laporan peristiwa atau pernyataan yang benar, aktual, penting, dan atau menarik dengan tujuan agar mudah dipahami isinya dengan cepat ditangkap maknanya. Sejalan dengan pendapat Sumandiria, Chaer (2010:2-4) menuturkan bahwa bahasa jurnalistik memiliki ciri-ciri sendiri yang membedakannya dengan ragam-ragam bahasa lainnya. Ciriciri ragam bahasa jurnalistik adalah sesuai dengan tujuan tulisan jurnalistik dan siapa pembaca ragam jurnalistik itu, yakni semua anggota masyarakat. Untuk itu, bahasa jurnalistik harus menerapkan tiga prinsip dalam menggunakan bahasa yaitu: hemat kata, tepat makna, dan menarik.

Penjelasan tersebut juga memberikan arti yang sangat bagus bagaimana bahasa merupakan salah satu unsur terpenting didalam pembuatan berita jurnalistik baik itu dimedia cetak maupun media online yang sudah sangat banyak berkembang saat ini. Untuk itulah pentingnya memperhatikan tata bahasa yang baik dan benar dengan memperhitungkan memperhitungkan keberagaman dimensi sosial konsumennya.

Perkembangan teknologi yang terus berkembang seperti saat ini yang telah banyak memunculkan jurnalistik juga media yang digunakan secara online. Jadi, dalam artian lebih luas baik itu media online maupun media cetak mempunyai peminat dan konsumennya sendiri sesuai dengan ketentuannya masing-masing. Seperti yang dijabarkan oleh Romli (2012:16-17), terdapat gambar, grafik, link terkait, audio, slide show, animasi, bahkan permainan interaktif di dalam pengemasan suatu jurnalistik online, sebagai elemen dasar maupun elemen tambahan dari jurnalistik online. Dari sekian banyak elemen yang menyertai jurnalistik online, yang akan dibahas pada penelitian ini adalah sajian jurnalistik online berupa teks berita dalam bentuk wacana tulis, yakin headline (judul berita) dan text (tubuh tulisan).

Marshall McLuhan sebagai penggagas teori "Medium is the message" menyatakan bahwa setiap media mempunyai tatabahasanya sendiri yakni seperangkat peraturan yang erat kaitannya dengan berbagai alat indra dalam hubungannya dengan penggunaan media. Setiap tata bahasa media memiliki kecenderungan (bias) pada alat indra tertentu. Oleh karenanya media mempunyai pengaruh yang berbeda pada perilaku manusia yang menggunakannya (Rakhmat, 1996: 248).

\section{Ejaan dalam Jurnalistik}

Menurut "Pedoman Pemakaian Bahasa dalam Pers" yang merupakan kesepakatan para peserta Karya Latihan Wartawan (KLW) ke-17 PWI Jaya yang dipimpin oleh H. Rosihan Anwar pada bulan November 1975 di Jakarta (dalam Chaer, 2010:97), 
bahwa bahasa pers pertama-tama harus menaati ejaan yang berlaku. mengatakan, secara umum EYD mengatur penggunaan huruf, penggunaan angka, penulisan kata, pemenggalan kata, penulisan kalimat dan penggunaan tanda baca, dan pedoman penyesuaian unsur/ejaan asing ke dalam bahasa Indonesia (Chaer, 2010:97).

\section{Kalimat dalam Jurnalistik}

Menurut Gory Keraf (1994:35), kalimat merupakan suatu bentuk bahasa yang mencoba menyusun dan menuangkan gagasan-gagasan seseorang secara terbuka untuk dikomunikasikan kepada orang lain. Sebuah kalimat yang efektif mempersoalkan bagaimana dapat mewakili secara tepat isi pikiran atau perasaan pengarang, bagaimana dapat mewakilinya secara segar, dan sanggup menarik perhatian pembaca.

Dalam bukunya yang berjudul Kalimat Jurnalistik, secara detail Dewabrata (2006) menjelaskan mengenai kalimat jurnalistik. Menurut Dewabrata, kalimat jurnalistik umumnya pendek-pendek. Selain itu, kalimat jurnalistik harus memiliki susunan penalaran yang runut. Munculnya variasi-variasi bahasa jurnalistik seperti yang telah diuraikan di atas dipakai untuk meningkatkan daya tarik tulisan. Hal ini dikarenakan bahasa jurnalistik merupakan proses kreatif, begitu sarat dengan diksi dan unsur kreasi. Tujuannya adalah untuk menghindari kejemuan pembaca dan menarik perhatian pembaca.

1) Subjek di Awal Kalimat

Menempatkan subjek pada awal kalimat adalah cara paling mudah untuk menampilkan kalimat jurnalistik variatif (Sumandiria, 2006:63). Penempatan subjek di awal kalimat memudahkan pembaca menangkap pengertian dan menarik kesimpulan, terlebih jika kalimat tersebut termasuk kalimat pendek yang terdiri dari beberapa kata saja.

2) Predikat pada Awal Kalimat

Pada pola konvensional, kalimat secara umum dimulai dengan subjek, kemudian disusul dengan predikat, objek, dan keterangan. Bahasa jurnalistik memperbolehkan penyusun berita untuk menempuh cara non konvensional sejauh tidak bertentangan dengan kaidah bahasa baku. Hal ini bertujuan untuk menghindari kejenuhan, karena bahasa jurnalisrtik bukan bahasa yang monoton dan kaku. Salah satu pilihan adalah menempatkan predikat pada awal kalimat (Sumandiria, 2006:64).

Kalimat berkronstruksi inversi lebih menekankan aspek kerja atau perbuatan. Pasalnya, susunan kalimat dalam konstruksi ini dibalik menjadi predikat lalu objek. Variasi ini digunakan untuk memberikan penekanan atau sorotan yang lebih terhadap predikat, atau sekedar memberikan kemenarikan dari variasi pola kalimat tersebut. (Sarwoko, 2007:111).

3) Kata Modal pada Awal Kalimat

Kata modal bisa mengubah arti secara keseluruhan yang terdapat pada sebuah kalimat. Kata modal bisa menentukan suatu hal, tetapi juga bisa membuatnya samar. Variasi kalimat dapat dilakukan dengan cara menempatkan kata modal pada awal kalimat. Namun, sebaiknya penggunaan kata modal ini jangan terlalu sering, karena bisa melebahkan dan mengaburkan makna (Sumandiria, 2006:64).

4) Variasi Konjungsi

Dalam menerapkan hemat kata, konjungsi pada konteks-konteks tertentu dapat ditanggalkan, alias tidak usah digunakan. Namun, kalau terpaksa harus digunakan demi menerapkan prinsip tepat makna, maka hendaknya harus digunakan secara bervariasi demi menerapkan prinsip bahasa yang menarik. Misalnya, jika sekali 
sudah menggunakan kata merkipun, maka di tempat lain harus digunakan kata biarpun, sungguhpun, walaupun, atau sekalipun (Chaer, 2010:86).

Terkait dengan variasi konjungsi, menurut Chaer (2010:75-76), untuk awal kalimat pada sebuah kalimat tunggal tidak boleh diawali dengan sebuah konjungsi. Apabila kalimat tersebut mempunyai hubungan dengan kalimat sebelumnya, maka kalimat tersebut tidak perlu berdiri sendiri sebagai sebuah kalimat, melainkan harus menjadi bagian (klausa) dari klausa sebelumnya sebagai sebuah kalimat majemuk.

5) Penggunaan Kalimat Aktif dan Pasif

Bahasa jurnalistik lebih mendahulukan kalimat aktif. Akan tetapi, kalimat-kalimat pada paragraf jurnalistik akan terasa membosankan apabila semuanya menggunakan kalimat aktif. Dalam beberapa hal, kalimat pasif mampu memberi tekanan makna dan nuansa rasa yang lebih kuat dibandingkan dengan kalimat aktif (Sumandiria, 2006:66). Agar menjadi menarik, kalimat pada bahasa jurnalistik dapat disajikan dalam bentuk kalimat pasif, bila yang ingin ditonjolkan atau dikedepankan adalah unsur objeknya (Chaer, 2010:85).

6) Penggunaan Kalimat Langsung dan Tidak Langsung

Seorang jurnalis tidak boleh mematikan karakter narasumber atau tokoh yang dikutip atau dikisahkannya. Karakter narasumber atau tokoh harus muncul untuk memberi penekanan sekaligus gambaran mengenai siapa sesungguhnya dia. Pemunculan karakter itu bisa dilakukan antara lain melalui penyajian kalimat kutipan langsung. Penulisan kalimat langsung sebaiknya divariasikan dengan kalimat-kalimat tak langsung (Sumandiria, 2006:66-67).

7) Penggunaan Kata Negasi

Kata negasi adalah kata yang mengandung unsur penyangkalan atau penolakan. Kata negasi disebut juga kata negatif. Ciri utama kata negasi atau kata negatif pada kalimat jurnalistik ialah penggunaan kata tak, tidak, bukan. Sesuai dengan konteksnya, kata negatif dapat memberi penguatan makna serta nilai sosial yang terdapat dalam kalimat (Sumandiria, 2006:68).

Khusus kata tidak, supaya tidak menimbulkan kebinungungan, sebaiknya ditaruh paling dekat dengan kata yang dinegasikan. Pada prinsipnya yang dinegasikan oleh kata tidak adalah kata terdekat di belakangnya. Berdasarkan variasi-variasi kalimat yang telah dijabarkan di atas, maka penulis akan meneliti variasi-variasi kalimat yang digunakan media online ROL pada kanal politik.

\section{Kode Etik Jurnalistik}

Dalam melaksanakan fungsi hak kewajiban dan peranannya, dunia pers harus menghormati hak asasi setiap orang yang dituntut bekerja secara professional dan terbuka untuk dikontrol oleh masyarakat. Dunia pers Indonesia telah menetapkan kode etik jurnalistik yang berfungsi untuk menjamin kemerdekaan pers dan memenuhi hak publik untuk memperoleh informasi yang benar. Oleh karena itu, wartawan Indonesia memerlukan landasan moral dan etika profesi sebagai pedoman operasional dalam menjaga kepercayaan publik dan menegakkan integritas sebagai professionalism. Ketetapan yang ditetapkan dengan nama kode etik jurnalistik tersebut harus ditaati oleh semua wartawan Indonesia, yang sebagaimana tercantum dalam table di bawah ini: 
Tabel 1.

Kode Etik Jurnalistik

\begin{tabular}{|l|l|}
\hline Nomor Pasal & Isi Pasal \\
\hline Pasal 1 & $\begin{array}{l}\text { Wartawan Indonesia bersikap independen, menghasilkan berita yang akurat, } \\
\text { berimbang dan tidak beritidak buruk. }\end{array}$ \\
\hline Pasal 2 & $\begin{array}{l}\text { Wartawan Indonesia menempuh cara-cara yang professional dalam melaksanakan } \\
\text { tugas jurnalistik. }\end{array}$ \\
\hline Pasal 3 & $\begin{array}{l}\text { Wartawan Indonesia selalu menguji informasi, memberitakan secara berimbang, } \\
\text { tidak mencampurkan fakta dan opini yang menghakimi, serta menerapkan asas } \\
\text { praduga tak bersalah. }\end{array}$ \\
\hline Pasal 4 & Wartawan Indonesia tidak membuat berita bohong, fitnah, sadis dan cabul. \\
\hline Pasal 5 & $\begin{array}{l}\text { Wartawan Indonesia tidak menyebutkan dan menyiarkan identitas korban kejahatan } \\
\text { susila dan tidak menyebutkan identitas anak yang menjadi pelaku kejahatan }\end{array}$ \\
\hline Pasal 6 & $\begin{array}{l}\text { Wartawan Indonesia tidak menyalahgunakan profesi dan tidak menerima suap. } \\
\text { Wartawan Indonesia memiliki hak tolak untuk melindungi narasumber yang tidak } \\
\text { ersedia diketahui identitas maupun keberadaannya, menghargai ketentuan }\end{array}$ \\
\hline Pasal 7 & $\begin{array}{l}\text { Wartawan Indonesia tidak menulis atau menyiarkan berita berdasarkan prasangka } \\
\text { atau diskriminasi terhadap seseorang atas dasar perbedaan suku, ras, warna kulit, } \\
\text { agama, jenis kelamin, dan bahasa serta tidak merendahkan martabat orang lemah, } \\
\text { miskin, sakit, cacat jiwa atau cacat jasmani. }\end{array}$ \\
\hline Pasal 8 & $\begin{array}{l}\text { Wartawan Indonesia menghormati hak narasumber tentang kehidupan pribadinya, } \\
\text { kecuali untuk kepentingan publik. }\end{array}$ \\
\hline Pasal 9 & $\begin{array}{l}\text { Wartawan Indonesia segera mencabut, meralat dan memperbaiki berita yang keliru } \\
\text { dan tidak akurat disertai dengan permintaan maaf kepada pembaca, pendengar dan } \\
\text { atau pemirsa. }\end{array}$ \\
\hline Pasal 10 & Wartawan Indonesia melayani hak jawab dan hak koreksi secara proporsional. \\
\hline Pasal 11
\end{tabular}

Sumber: (Syah, 2012:173)

Dengan adanya kode etik tersebut, tentunya wartawan sebelum membuat berita harus terlebih dahulu memperhatikan Kode etik Jurnalistik yang sudah ditetapkan, sebagai landasan utama. Masduki dalam bukunya Kode Etik Jurnalistik (2005:57), mengatakan bahwa berbagai kepentingan bisa saling berbenturan menyangkut hak publik untuk mendapatkan informasi dan keinginan media untuk mempublikasikan informasi berhdapan dengan sistem yang berlaku di masyarakat.

Pemberitaan dengan melihat kode etik jurnalistik juga sebagai penyeimbang dari berbagai bentuk kepentingan yang melibatkan media massa. Dijelaskan oleh Masduki, bahwa akurasi berarti pers wajib menempatkan kepentingan publik diatas kepentingan pribadi dan memberitakan berita yang kurang akurat atau menyesatkan. Jika diketahui informasi kurang akurat, pers wajib meminta maaf disertai koreksi. Pers juga wajib membedakan antara opini dan fakta. Privasi artinya, pers wajib menghormati privasi narasumber. Menerbitkan privasi narasumber tanpa ijin dianggap ganguan atas privasi seseorang. Pornografi berarti, pers tidak menyiarkan produk yang berbau zina. Media pronografi tidak termasuk pers. Sumber rahasia berarti pers mempunyai kewajiban moral untuk melindungi sumber-sumber informasi rahasia atau disangka melakukan konfidensial (Masduki, 2005:57)

Apabila wartawan melakukan liputan kriminalitas, wartawan diwajibkan menghindarkan identifikasi keluarga atau teman yang dituduh atau kejahatan tanpa seizin mereka. Pers harus meminta izin keluarga terlebih dahulu sebelum melakukan wawancara dan penyebutan nama anggota keluarga. Pers harus tetap menghormati hak jawab dan 
bantahan dari narasumber. Terakhir, pers diwajibkan menghindari prasangka atau sikap merendahkan seseorang berdasarkan ras, warna kulit, agama, jenis kelamin atau kecenderungan seksual dan terhadap kelemahan fisik dan mental penyandang cacat (Masduki, 2005:58)

Dari 11 pasal yang ada tentang kode etik jurnalistik, bukan berarti akan digunakan semuanya untuk membahas tentang kelayakan berita yang dihasilkan oleh para citizen journalist. Karena, harus juga memperhatikan kesesuaian antara berita yang dihasilkan oleh para citizen journalist dengan wartawan professional. Jadi, di sini penulis mengambil pasal 1,2 dan 3 yang dianggap sesuai untuk digunakan sebagai pedoman untuk menganalis tentang kelayakan berita yang dihasilkan oleh citizen journalist. Hal ini juga disebabkan pasal-pasal lain yang di luar ketiga pasal tersebut berbeda dengan pembahasan yang sedang dibahas dan berkaitan dengan berita criminal. Sedangkan, disini pembahasan mengenai berita yang dihasilkan oleh citizen journalist adalan laporan yang mereka hasilkan dari kegiatan jurnalistik yang mereka lakukan baik itu secara aktif maupun pasif.

Dengan melihat penjelasan di atas, maka akan di coba jelaskan dengan menganalisis bagian dari ketiga pasal yang dijadikan acuan tersebut. Maka, penulis akan memberikan bagian penjelasan dengan memperhatikan kelengkapan $5 \mathrm{~W}+1 \mathrm{H}$ dan Tipe Peliputan, Sifat berita, Relevansi Sumber Berita dan Kelengkapan Keterangan foto dan Tidak Mencampurkan Fakta dan Opini Wartawan.

\section{PASAL 1}

a. Keakuratan Informasi

Keakuratan sebuah berita dapat dilihat dari apakah berita tersebut sudah memiliki standar praktik jurnalistik yakni formula $5 \mathrm{~W}+1 \mathrm{H}$, yang terdiri dari what, who, when, where, why dan how.

b. Berimbang

Berita yang seimbang yaitu dengan memperhatikan porsi informasi yang diterima dari dari masing-masing pihak. Sehingga, berita yang hasilkan tidak memberikan kesan yang menyudutkan sebelah pihak.

Dalam bukunya yang berjudul Analisis Framing Konstruksi Ideologi dan Politik Media (2006:22), Eriyanto mengatakan bahwa keberimbangan berita diukur dengan menghitung berapa banyak ruang dan waktu yang diberikan media untuk menyajikan pendapat atau kepentingan salah satu pihak.

\section{PASAL 2}

a. Faktual

Berita jurnalistik yang layak bersifat faktual. Hal ini dapat diartikan, sebuah peristiwa yang diberitakan memiliki fakta yang sungguh nyata, bukan rekayasa yang dibuat oleh wartawan (Siregar, 1998:55).

Dimana fakta sosiologis adalah fakta yang diperoleh wartawan dari hasil pengamatan langsung di lapangan dan pendapat narasumber digunakan sebagai pelengkap berita, oleh karena itu fakta haruslah ditampilkan apa adanya. Wartawan sama sekali tidak diperbolehkan mengubah fakta itu. Menambah atau mengurangi fakta adalah tabu. Itu bertentangan dengan hakikat tugas wartawan, yaitu melaporkan peristiwa, melaporkan fakta (Siregar, 1998: 217). Berita dikatakan faktual apabila memenuhi sifat fakta sosiologis

b. Relevansi Sumber Berita

Sumber berita yang relevan dapat memberikan informasi yang lebih lengkap dan akurat mengenai peristiwa yang dialaminya. Jadi, idealnya sumber berita adalah orang yang mengalami kejadian dari yang ingin diberitakan tersebut. 


\section{c. Kelengkapan Foto}

Selain berita yang dibuat harus factual dan mempunyai sumber yang jelas, sebuah berita juga harus dilengkapi oleh keterangan yang jelas dan akurat, seperti salah satunya yaitu wartawan harus memberi kelengkapan photo untuk menambah kelengkapan laporan dari peristiwa yang mereka hasilkan.

\section{PASAL 3}

a. Opini Wartawan

Pada prinsipnya pers wajib membedakan antara fakta dan opini dalam berita. wartawan tidak boleh memasukkan opini pribadi mereka ke dalam penulisan berita (Masduki, 2004:47).

\section{PENUTUP}

Citizen Journalism merupakan sebuah fenomena baru dalam dunia jurnalistik. Dengan konsep yang melibatkan masyarakat sebagai objek sekaligus subjek membuat citizen journalism menjadi lebih menarik dan semakin berkembang. Hal ini, disebabkan berbagai factor yang salah satunya adalah dengan banyaknya masyarakat yang menjadi penulis, sehingga berita yang dikirimkan semakin banyak dan up date.

Namun, banyak pihak masih meragukan tentang kelayakan berita yang dihasilkan oleh citizen journalist ini dengan didasari dari melihat perbandingan dari kualitas berita yang dihasilkan dengan oleh para jurnalis professional. Akan tetapi, analisis kelengkapan berita dengan memperhatikan unsur $5 \mathrm{~W}+1 \mathrm{H}$ memberikan bukti bahwa berita yang dihasilkan oleh citizen journalist sudah dilayak dikatakan berita yang baik.

Disamping itu, dengan menggunakan dan memperhatikan Kode Etik Jurnalistik tentunya berita yang dihasilkan oleh para citizen journalist tidak perlu lagi diragukan tentang kelayakannya. Apalagi dengan melihat berita yang dihasilkan mereka adalah berita ringan dan juga dengan sumber yang jelas sehingga terus dipercaya masyarakat dengan berita-berita yang memang layak untuk dikonsumsi.

\section{DAFTAR PUSTAKA}

\section{Arif, Ahmad. 2010. Jurnalisme Bencana, Bencana Jurnalisme. Jakarta KPG}

Chaer, Abdul. 2010. Kesantunan Berbahasa. Jakarta: Rineka Cipta.

Darmadi, Bambang, Y.B. Margantoro, Budi Sutedjo Dharma Oetomo. 2006. Mahir Jurnalistik. Amora. Books

Effendy, Oenong Uchjana. 2003. Sosiologi Komunikasi Massa. Bandung: PT. Rineka Cipta

Eriyanto. Analisis Framing Konstruksi, Ideologi dan Politik Media. Yogyakarta: LKIS

Keraf, Gorys. 1994. Tata Bahasa Indonesia. Ende Flores: Nusa Indah.

Irianto, Yosal. 2005. Media Relation: Konsep, Pendekatan dan Praktik. Simbiosa Rektama Media

Ishawara, Luwi. 2011. Jurnalisme Dasar. Jakarta: Kompas Media Nusantara 
Kusumaningati, Iman FR. 2012. Jadi Jurnalis Itu Gampang!!!. Jakarta: PT Elex media Komputindo

Masduki. 2005. Kode Etik Jurnalistik. Yogyakarta: UII Press

Nurudin. 2009. Jurnalisme Masa Kini. Jakarta: PT. Raja Grafindo Persada

Nugraha, Pepih. 2012. Citizen Journalism: Pandangan, Pemahaman dan Pengalaman. Jakarta: PT. Kompas Media Nusantara.

Panuju, Redi. 2005. Nalar Jurnalistik : Dasarnya dasar-dasar Jurnalistik. Malang: Bayumedia

Quinn, Stephen dan Lamble. 2008. Online Newsghatering. USA. Focal Press.

Rakhmat, Jalaluddin. 1996. Teori-teori Komunikasi. Bandung : PT. Remaja Rosdakarya.

Romli, Asep Syamsul M. 2012. Jurnalistik Online. Bandung: Nuansa Cendikia.

Sarwono, Billy, Dedy Nur Hidayat et al. 2008. 75 Tahun M. Alwi Dahlan: Manusia Komunikasi, Komunikasi Manusia. Jakarta: Kompas Media Nusantara

Siregar, Ashadi. 2006. Etika Komunikasi. Yogyakarta: Pustaka

Siregar, Amir Effendy. 2009. Akan matikah Media Cetak?. Artikel. H. U. Kompas, Sabtu 05 September 2009

Sukardi, Wina Armada. 2008. Kode Etik Jurnalistik \& Dewan Pers. Jakarta: Dewan Pers

Sumadiria, Haris 2006. Jurnalistik Indonesia. Bandung: Simbiosa Rekatama Media.

Syah, Sirkit. 2012. Rambu-rambu Jurnalistik. Yogyakarta: Pustaka Pelajar 